\title{
A Politico-ECONOMIC ANALYSIS OF MiNiMUM WAGES AND WAGE SUBSIDIES
}

\author{
ANTONIS ADAM \\ THOMAS MOUTOS
}

CESIFO WORKING PAPER NO. 1810

CATEGORY 4: LABOUR MARKETS

SEPTEMBER 2006

An electronic version of the paper may be downloaded

- from the SSRN website:

- from the RePEc website:

- from the CESifo website:

www.SSRN.com

Www.RePEc.org

www.CESifo-group.de 


\title{
A Politico-ECONOMic ANALysis of Minimum WAGES AND WAGE SUBSIDIES
}

\begin{abstract}
In this paper we construct a political economy model in which minimum wages are determined according to the wishes of the median voter. Using the minimum wage scheme as the status quo, we show that the replacement of minimum wages by wage subsidies guaranteeing the same (pre-tax) level of income (achieved by the government supplementing the wage income of workers by a subsidy equal to the difference between the competitive wage rate and the minimum wage rate), is not likely to receive political support unless it is supplemented by increased taxation of profits (after-tax profits are also likely to increase). Moreover, we show that the likelihood of implementation of wage subsidies is undermined by the existence of a heterogeneous labour force.
\end{abstract}

JEL Code: D72, E24, E62.

Keywords: minimum wages, wage subsidies, median voter, political economy.

\author{
Antonis Adam \\ University of Cyprus \\ Department of Economics \\ P.O. Box 20537 \\ 1678 Nicosia \\ Cyprus \\ aadam@ucy.ac.cy
}

Thomas Moutos

Athens University of Economics and

Business

Patission 76

Athens 10434

Greece

tmoutos@aueb.gr

We wish to thank seminar participants at the University of Cyprus and Margarita Katsimi and Ronnie Schoeb for helpful comments and suggestions. 


\section{Introduction}

The use of minimum wages as a way to reduce poverty and redistribute income has re-emerged forcefully in recent policy discussions ${ }^{1}$. One reason for the renewed popularity of minimum wage schemes -especially in the United States and the United Kingdom- is the large rise in wage (and income) inequality in these countries during the last decades. ${ }^{2}$ Yet, as Phelps (1994, 1997), Sinn (2000, 2005a) and Dreze (2002), have forcefully argued, if the objective of minimum wages is to prevent the income of some workers from falling below some socially acceptable level, then the granting of employment or wage subsidies is a superior method for achieving this objective. Nevertheless, policy-makers in most countries remain reluctant to move in this direction, whereas in some countries (e.g., Germany) the imposition of a statutory minimum wage has moved up in the political agenda.

In this paper we construct a political economy model in order to explain the lack of political will to revoke (the explicitly or implicitly) existing system of minimum wages in favour of employment or wage subsidies. ${ }^{3}$ In contrast with other contributions emphasizing the large fiscal cost of employment subsidies as a (possibly) inhibiting factor for their implementation, we also take into account the

\footnotetext{
${ }^{1}$ Freeman (1996) provides a discussion of the distributional impact of minimum wages. Dolado et. al. (2000) note the change in attitude of OECD towards minimum wages by contrasting OECD (1994), in which study it is recommended that there must be a switch away from minimum wages to more direct instruments of redistribution, with OECD (1998), where it is recommended that minimum wages should be a constituent of a well-designed policy package.

${ }^{2}$ Another reason may be that more recent studies have questioned both the theoretical presumption of a negative employment effect as a result of a minimum wage increase and its empirical relevance (see, Card and Krueger (1995), Neumark and Wascher (2000), and Manning (2003) for comprehensive reviews of both the empirical and the theoretical debates).

${ }^{3}$ The view that minimum wage legislation is the outcome of the pressure of vested interests is widely shared (e.g., Cox and Oaxaka (1982), Saint-Paul (2000)). Moreover, as Sobel (1999) has pointed out, for the United States, minimum wages have seldom been set at levels consistent with the goals of reducing poverty or household inequality; instead they have been the outcome of political economy pressures. The abolishment of Wages Councils by the Conservative government in the United Kingdom in 1993 (which set minimum wages for 2.5 million workers), and the (re)-instatement of a national minimum wage by the Labour government in 1999 is also a case of action which was (at least partly) shaped by political pressures.
} 
reduction in the wage rate of incumbent employees which a rise in aggregate employment generates. We find that this latter effect, in tandem with the increased profits that employment subsidies bring about, may be largely responsible for the lukewarm attitude towards the implementation of employment subsidy schemes.

In the following section we capture the existence of political pressure indirectly through the median-voter model. ${ }^{4}$ (Later on we also discuss briefly possible ramifications to our conclusions arising from the use of a lobbying model.) The median voter is assumed to be a worker (cum household) whose only income is derived either from the sale of her labour services (when employed) or from state support in the form of unemployment benefits. In this framework, the imposition of a minimum wage above the competitive wage (i.e., the one ensuring full employment) generates both benefits and costs for the median voter. The benefits arise from the higher marginal product of labour and wage rate that a fall in employment generates. The costs arise from the higher taxes that a smaller number of employed workers must pay in order to support the higher number of unemployed. As one may expect, we find that in the absence of taxes on income from profits, the utility of the median voter is maximized when at the chosen minimum wage the elasticity of labour demand is equal to one.

The median-voter mediated politico-economic equilibrium of the previous section implies that the median voter has an interest in increasing labour's marginal product which can be achieved only through an unemployment-generating minimum wage. An implication of this is that some employment-increasing and poverty-alleviating policies which have been recently proposed may not be politically viable. In section 3

\footnotetext{
${ }^{4}$ This model and its predictions are best interpreted when the concept of the median voter is not taken literally, but viewed as a convenient analytical device. As Alesina and Rodrik (1994) have observed, the median voter captures the basic idea that any government is likely to be responsive to the wishes of the majority when key distributional issues are at stake.
} 
we ask the following question. Would the median voter support a policy change which guarantees to the workers a level of pre-tax income equal to the minimum wage, and which is achieved by the government supplementing the wage income of workers by a subsidy equal to the difference between the competitive (i.e., full employment) wage rate and the minimum wage rate $?^{5}$ We consider two ways of financing this scheme. The first one assumes that only the (wage) income tax rate adjusts so as to finance the cost of subsidies. In this case we find that, most likely, the median voter would not support this policy even though it results in a rise in output. This is because the policy involves a reduction in the share of national income accruing to labour, and wage earners will have to shoulder the rise in tax obligations which the financing of the subsidies implies.(In effect, this policy is a subsidy to the owners of firms since the real wage declines). This probably explains the unwillingness of policy makers (intent on winning elections) to implement the more efficient policy. However, our analysis suggests that the median voter would be wiling to support the granting of subsidies if only the tax rate on profits adjusts so as to finance the cost of wage subsidies. Moreover, we show that after-tax profits may not decline even if the profit tax rate increases, thus the policy can also be compatible with constraints imposed by globalization.

In section 4 we drop the assumption of a homogeneous labour force and consider two groups of workers. These groups (e.g., skilled and unskilled) differ only in the amount of effective labour units which have at their disposal per unit of time; skilled workers have more effective units per unit of time (hour, day, or month) than their unskilled counterparts. A (binding) minimum wage which is imposed per unit of time implies that some of the unskilled workers will not be employed - those employed

\footnotetext{
${ }^{5}$ For more elaborate schemes to combat unemployment without jeopardizing the living standards of low-paid workers see, Phelps (1997), Orsag and Snower (2000, 2003), Sinn (2005b, 2006) and Knabe (2006) and Knabe et al. (2006).
} 
will earn the minimum wage per unit of time, whereas skilled workers will earn (per unit of time) an amount equal to their effective labour units times the wage rate per effective unit of labour. Assuming that the political equilibrium is determined according to the interests of skilled workers, ${ }^{6}$ we show that the political support for wage subsidies is reduced. This is because the resulting expansion in employment will reduce the wage rate per effective unit of labour, and thus the pre-tax incomes of the always employed (and thus not facing the probability of unemployment spells) skilled workers.

This lack of political support for wage subsidies inherent in a model in which the policy maker heeds to the wishes of skilled workers can obviously be overturned if the politico-economic equilibrium shifts to accommodate the wishes of unskilled workers and, perhaps more importantly, the influence of firm owners. To this purpose, in the concluding section of the paper we discuss possible ramifications to our conclusions regarding the political (non)-viability of wage subsidies arising from the use of a lobbying model.

\section{Minimum wages}

We consider an economy populated by a fixed number of households and of a (sufficiently) large number of perfectly competitive firms. We assume that firms are owned by a small fraction of households, and that for the rest of the households, labour income is their only source of household income. All households (with the exception of those owning the firms) own one unit of labour, which they offer inelastically. We will assume that the politico-economic equilibrium is determined according to the Downsian (Downs, 1957) model of electoral competition.

\footnotetext{
${ }^{6}$ If the median voter is an unskilled worker, then the qualitative nature of the results remains the same as in the case of homogeneous labour.
} 


\subsection{The Model}

All firms are identical and produce a homogeneous good with the use only of labour. The production function exhibits diminishing returns, and for simplicity we assume that it takes the form

$$
Q=a L-\frac{b}{2} L^{2}
$$

where $L$ stands for the units of labour used ${ }^{7}$. Each unit of labour earns the same wage rate, $w$. Profit maximization implies that the demand for labour is,

$$
L_{d}=\frac{a-w}{b} .
$$

Assume, for the moment, that there no legal restrictions on the sale of labour services. If we normalize the total number of workers (and of labour units), $L_{S}$, in the economy to be equal to 1 , then the competitive (i.e., full employment) wage rate will be equal to

$$
w_{C}=a-b
$$

The elasticity of labour demand with respect to the wage rate is, $\varepsilon_{L, w}=-w /(a-w)$.

At the competitive wage rate, the value of the elasticity is $\varepsilon_{L, w_{C}}=(b-a) / b$. We assume that $b<a<2 b$. This assumption ensures that at the competitive wage the elasticity is less than one in absolute value, implying that the imposition of a minimum wage above the competitive wage will increase aggregate wage income even though it results in a fall in employment. ${ }^{8}$

\footnotetext{
${ }^{7} \mathrm{We}$ (implicitly) assume the existence of another factor (e.g., physical capital ) which is in fixed supply and which is not owned by the median voter - thus labour's marginal product is decreasing. ${ }^{8}$ Had we assumed a Cobb-Douglas production function, say $Q=L^{\delta}$, then the labour demand elasticity with respect to the wage rate would be constant and equal to $(1 /(\delta-1))$, which implies an unreasonably high elasticity (close to 3 ) for reasonable assumptions about the share of labour in national income.
} 
Let $\bar{w}$ stand for the minimum wage that each firm has to pay in order to employ a worker. Then, as long as $\bar{w}>w_{C}$, some workers will be unemployed, and the unemployment rate will be equal to,

$$
u=1-L_{d}=\frac{b-a+\bar{w}}{b}
$$

It is obvious that a larger value of $\bar{w}$ implies that fewer individuals will be employed, and that the marginal product of labour and the wage rate will be higher. A rise in minimum wages thus results in an increase in the incomes of those remaining in employment. The (aggregate) profits associated with the minimum wage $\bar{w}$ are,

$$
\pi=\frac{(a-\bar{w})^{2}}{2 b}
$$

We assume that all labour income is taxed at a tax rate, $t$. The government may also raise revenue by taxing profits with a tax rate, $\tau$. We further assume that unemployed individuals receive an unemployment benefit which is proportional to the minimum wage, i.e. it is equal to $\phi \bar{w} \quad(0<\phi<1)$, with the value of $\phi$ having being "constitutionally" determined in the past, and thus not subject to current policy. We assume that unemployment benefits are also taxed at the same tax rate, $t$, and thus the government budget constraint is written as,

$$
t \bar{w}(1-u)+\tau \pi=\phi \bar{w} u(1-t) .
$$

We now turn to the determination of the minimum wage.

\subsection{Politico-economic equilibrium}

In what follows in this section we assume that the policy-maker implements the minimum wage which affords the highest utility to the median voter. The median voter in our model is a worker (cum household) whose income is derived either from 
the sale of her labour services or from state support in the form of unemployment benefits (when unemployed). Since, by assumption, all households are identical, we may think that before the political decision about the minimum wage is taken, each household assesses the probability of being among the lucky ones to find employment to be equal to the unemployment rate that the chosen minimum wage will generate. Thus, the median voter's expected after-tax income (and utility) is equal to

$$
V_{M V}=(1-t)[(1-u) \bar{w}+u \phi \bar{w}]
$$

We conceive that the median voter realizes that her preferred choice of the minimum wage implies through the government budget constraint a particular constellation of the income tax and the profit tax rates (and, indirectly, also of the unemployment rate). Assuming that the profit tax rate is fixed, and that it is the income tax rate which adjusts to keep the government's budget in balance ${ }^{9}$, we can use equation (6) to rewrite equation (7) as,

$$
V_{M V}=(1-u) \bar{w}+\tau \pi
$$

Equation (8) implies that the median voter, in the absence of taxes on profits, would care only about total labour income. Thus, if policy-makers cared only about the median voter, they would set the minimum wage at a level such that the (absolute) value of the elasticity of labour demand would be equal to 1 . As we will see, the ability to tax profits implies that the median voter (and policy-makers) may find it in their interest to implement a minimum wage which allows firms to earn more profits.

Using equations (4) and (5), we rewrite equation (8) as

$$
V_{M V}=\bar{w}\left(\frac{a-\bar{w}}{b}\right)+\tau \frac{(a-\bar{w})^{2}}{2 b}
$$

\footnotetext{
9 Alternatively, we could assume that it is only the profit tax rate which adjusts to satisfy the government budget constraint (with the wage income tax rate remaining constant). However, we are skeptical about the empirical plausibility of assuming that the profit tax rate can be determined by purely domestic considerations in a world of high capital mobility.
} 
The minimum wage which maximizes the utility of the median voter is,

$$
\bar{w}=\frac{a(1-\tau)}{2-\tau}
$$

Equation (10) implies that the chosen minimum wage is a decreasing function of the profit tax rate. A higher profit tax rate implies -ceteris paribus - that the median voter expects a larger gain from a wage moderation which results in higher profits, as a larger part of the increase in profits is captured by the median voter through a reduction in her tax obligations. The unemployment rate, and (aggregate) profits corresponding to the chosen minimum wage are,

$$
\begin{aligned}
& u=1-\frac{a}{b(2-\tau)} \\
& \pi=\frac{a^{2}}{2 b(2-\tau)^{2}}
\end{aligned}
$$

Consequently, the utility of the median voter is,

$$
V_{M V}=\frac{a^{2}}{2 b(2-\tau)}
$$

We note that the utility of the median voter is increasing in the profit tax rate. This holds, even though a higher profit tax rate has a negative impact on the equilibrium minimum wage, because it implies both a lower unemployment rate and a larger contribution by the owners of firms to the financing of unemployment benefits.

\section{Employment Subsidies}

The median-voter mediated politico-economic equilibrium of the previous section implies that the median voter has an interest in increasing labour's marginal product which can be achieved only through an unemployment-generating minimum wage. An implication of this is that some employment-increasing policies which have recently been proposed may not be politically viable. 
In what follows we examine under what conditions, given the existence of the minimum wage system, the conversion to a system of income support through wage subsidies is politically viable. To this purpose we assume that voters are presented with the policy choice of instituting a subsidy scheme such that even though the wage rate drops to its full employment level, no worker's total income drops to a level lower than the minimum wage as determined in the previous section. This is achieved by the government supplementing the income of workers by an amount equal to the difference between the minimum wage and the wage that the firms are willing to pay if there is full employment $\left(L_{S}=1\right) .{ }^{10}$ In terms of Figure 1, the aggregate fiscal cost of the subsidy will be equal to area $w_{c} \bar{w} d f$, the rise in national income will be equal to area $L_{d} c f L_{S}$, whereas the rise in pre-tax profits will be equal to area $\bar{w} w_{c} f c$.

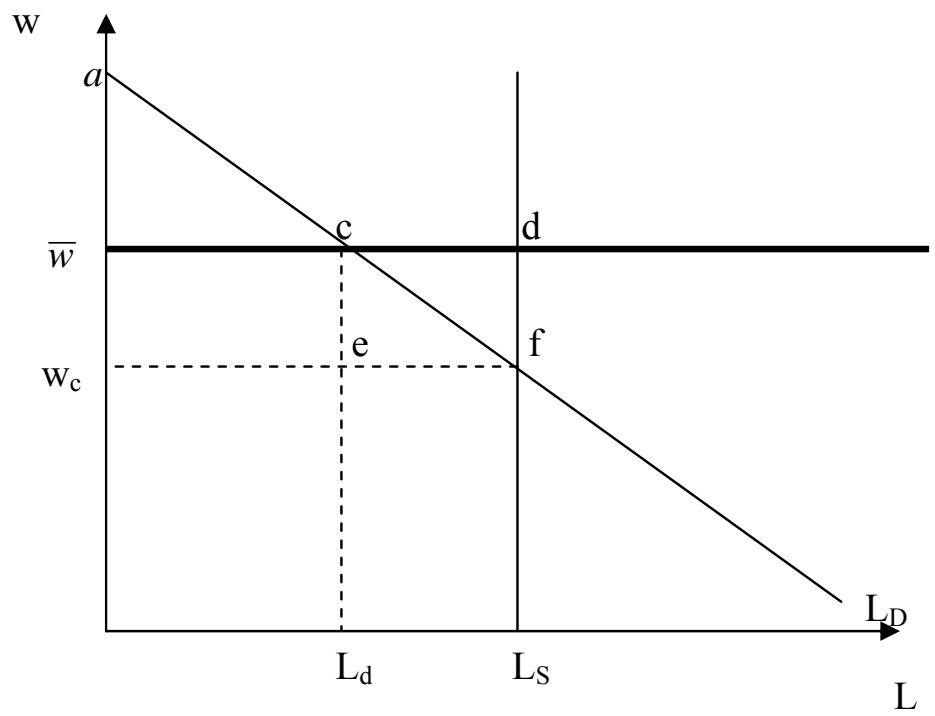

Figure 1: The effects of wage subsidies

\footnotetext{
${ }^{10}$ An alternative scheme would be to provide wage subsidies to the firms for employing those that would have been unemployed if the minimum wage scheme remained in existence. However, such schemes are usually plagued by moral hazard problems and large administrative costs. Nevertheless, see Knabe et al. (2006) for a scheme which avoids some of the pitfalls of previous subsidy schemes, and Knabe (2006) for an analysis of how the proposed scheme of double marginal subsidies (a concept developed by Schoeb and Weimann (2003) where for each new employee also one incumbent employee is subsidized) can reduce the fiscal cost of subsidies and make them more palatable to the electorate.
} 
Using equations (3) and (10), the aggregate cost of the subsidy which the government would have to pay is

$$
s=\bar{w}-w_{C}=\frac{b(2-\tau)-a}{2-\tau} .
$$

Aggregate output at full employment is,

$$
Q_{C}=\frac{2 a-b}{2}
$$

whereas the (pre- tax) profits with this subsidy scheme will be equal to

$$
\pi_{C}=b / 2
$$

With full employment, the only government outlay is the spending on subsidies, thus the government budget constraint is,

$$
t_{C} \bar{w}+\tau \pi_{C}=s
$$

The question is whether the median voter would be willing to endorse such a subsidy scheme. The answer to this crucially depends on whether it will be the (labour) income tax rate or the profit tax rate which adjusts so as to satisfy the government budget constraint. We examine each of these cases in turn.

\subsection{Adjusting the (labour) income tax rate}

Solving equation (17) for $t_{c}$ we get,

$$
t_{C}=\frac{b\left(4(1-\tau)+\tau^{2}\right)-2 a}{(1-\tau) a}
$$

The median voter's after-tax income and utility would in this case (i.e., of full employment) be,

$$
V_{M V}^{t}=\left(1-t_{C}\right) \bar{w}=\frac{2 a+a(1-\tau)-b\left(4(1-\tau)+\tau^{2}\right)}{2-\tau}
$$

Before proceeding with the comparison of median-voter utility derived from the status quo (as determined by equation (13) ) and the one resulting from the subsidy scheme, 
it is worth noting that both before and after-tax profits would be higher under the subsidy scheme (since it reduces the wage rate per effective unit of labour).

Using equations (13) and (19), we find that the utility (of the median voter) from the subsidy scheme will be higher than under the minimum wage one, if

$$
(2-3 \tau)\left(\frac{a}{b}\right)^{2}-2(2-\tau)(3-\tau) \frac{a}{b}+2(2-\tau)^{3}<0 .
$$

As expression (20) makes clear, the (relative) preference for the two schemes depends only on the ratio $(a / b)$ and the profit tax rate, $\tau$. In Figure 2, the solidly drawn schedule depicts combinations of $(a / b)$ and $\tau$ for which the median voter is indifferent between the minimum wage and subsidy schemes (i.e., for which the lefthand side of expression (23) is equal to zero). Points above (below) this schedule imply preference for subsidies (minimum wages).

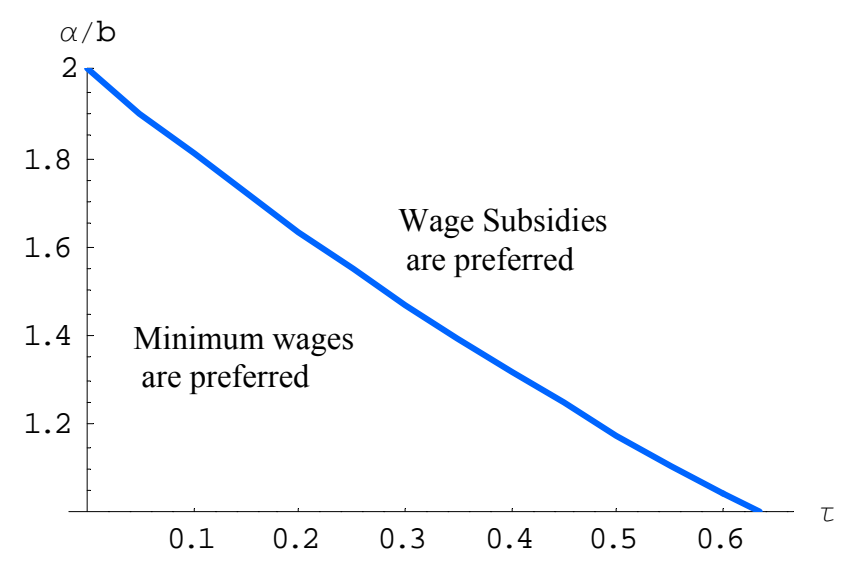

Figure 2: Combinations of $a / b$ and $\tau$ for which the median voter is indifferent between minimum wages and wage subsidies.

However, even though we have some knowledge about the value of $\tau$ in actual economies, we have no direct knowledge about the ratio $(a / b)$ so as to be able to determine whether data for real world economies imply points above or below this schedule. Nevertheless, our model implies a relationship between the ratio $(a / b)$ and some variables for which we do have some knowledge. Using the equations (i.e. (1), 
(10), (11) and (12)) pertaining to the minimum wage case (which is the status quo case), we find that

$$
\frac{a}{b}=\frac{\phi(2-\tau)}{\mu(3-2 \tau)-2(1-\tau)(1-\phi)}
$$

where, $\mu=((w(1-u)+u \phi w) / Q))$ is the ratio of labour income (including unemployment benefits) to output. ${ }^{11}$ For any given values of $\mu$ and $\phi$, equation (21) gives the combinations between $(a / b)$ and $\tau$ implied by the model. We can thus use our knowledge about actual values of $\mu$ and $\phi$ (the replacement rate) in order to determine whether the combinations between $(a / b)$ and $\tau$ implied by our model lie above or below the solid schedule.

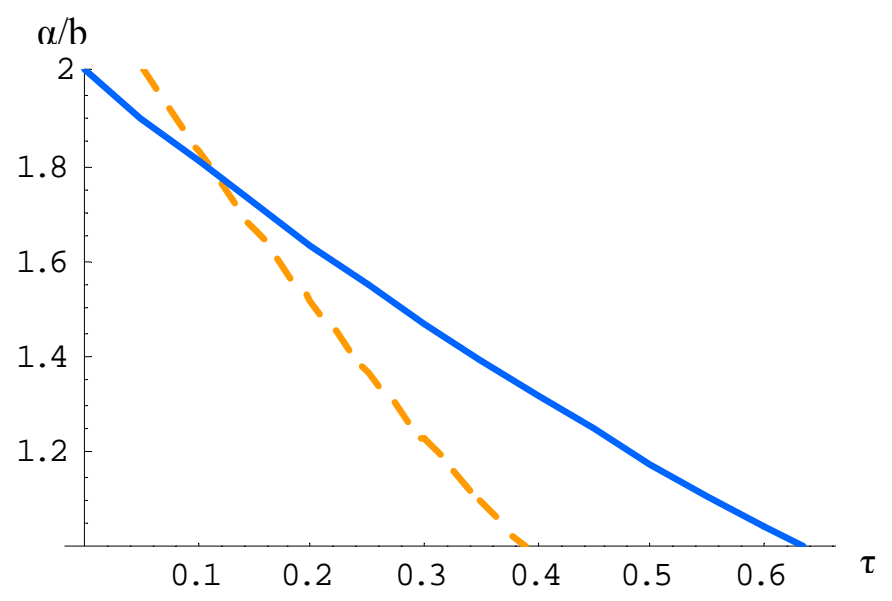

Figure 3: Combinations of $a / b$ and $\tau$ implied by the model (dashed schedule, $\mu=0.65$, $\phi=0.85$ ) and required for the adoption of subsidies (those above the solid schedule).

The dashed schedule in Figure 3 shows the combinations of $(a / b)$ and $\tau$ implied by the model for $\mu=0.65$ and $\phi=0.85 .^{12}$ We see that only for countries with (average)

\footnotetext{
${ }^{11}$ We note that the labour share (defined as the ratio of employee compensation to output) is independent of $(a / b)$ in our model.

${ }^{12}$ The share of labour in business sector output for the seven largest economies in the OECD has, on average, been slightly more than $65 \%$ for the period $1980-1995$, and was ranging from about $63 \%$ in Italy to about $70 \%$ in the United Kingdom (see, Poterba (1999)). Given that $\mu$ represents in our model
} 
profit tax rates lower than (about) 13\% would the median voter be willing to endorse the shift from a minimum wage scheme to a scheme of wage subsidies. Figure 4 reproduces the curves of figure 3 , but now the dashed schedule shows the combinations of $(a / b)$ and $\tau$ implied by the model for $\mu=0.70$ and $\phi=0.85$. In this case, the dashed schedule lies entirely below the solid one, and independent of the value of the profit tax rate the median voter would be against the institution of wage subsidies. The figure also shows that the same holds true if $\phi=1$ (dotted schedule).

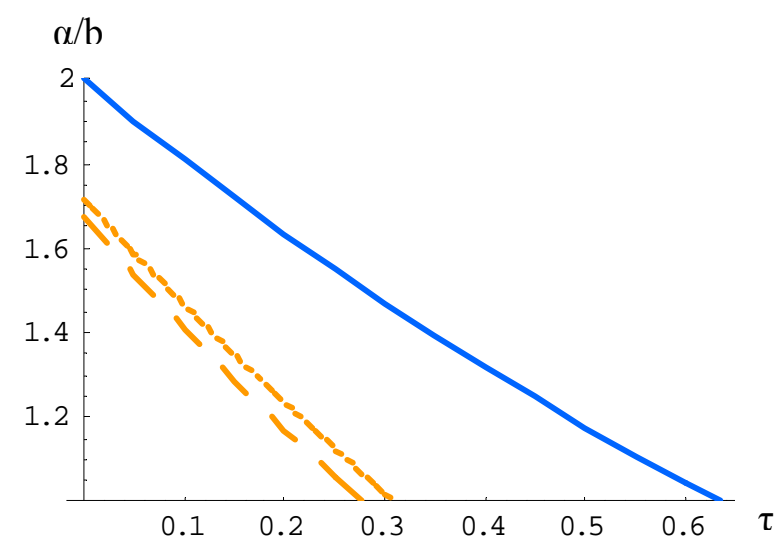

Figure 4: Combinations of $a / b$ and $\tau$ implied by the model $(\mu=0.70$ and either $\phi=0.85$ or $\phi=1)$ and required for the adoption of subsidies (above the solid schedule)

These figures suggest that although wage subsidies are efficiency enhancing, there may be not be, at the moment, enough political support for their implementation in most OECD countries. Nevertheless, the ongoing process of globalization and the downward pressure on profit tax rates which this implies may bring about the

\footnotetext{
a measure greater than the share of labour in business sector output (since it includes in the numerator the income received by the unemployed), we regard $\mu=0.65$ is close to the lower bound for empirically relevant values of $\mu$. Unlike $\mu$, actual values of the net replacement rate for average production workers differ a lot between OECD countries, and were ranging in 1997 from 0.54 in Italy to 0.85 in the Netherlands for couples with two children, and from 0.33 in Ireland to 0.79 in Portugal for single persons (see, OECD (1999)). We thus regard the value of $\phi=0.85$ as close to the upper bound for empirically relevant values of $\phi$.
} 
conditions (i.e., a low profit tax rate) under which wage subsidies are a politically viable alternative to minimum wages.

\subsection{Adjusting the profit tax rate}

Assume now that the (labour) income tax rate remains constant and that it is the profit tax rate which adjusts to finance the wage subsidies. In this case, the median voter will achieve higher utility under the subsidy scheme since the after-tax wage is held constant (as $t$ is constant, and every worker gets the minimum wage), and at the same time there is no unemployment. Comparing the resulting utility under the two regimes, we find that wage subsidies are preferable if

$$
\frac{2 b}{2 b+(\phi-1)(2 b-a)}>1 \text {. }
$$

This inequality indeed holds if $\phi<1$.

The political feasibility of wage subsidies may not be guaranteed in this case as well if globalization places an effective limit on the after-tax rate of return of mobile factors. A natural question that comes up in this respect is whether after-tax profits are higher or lower under the wage subsidy scheme; although gross profits are higher, the profit tax rate is also higher in order to finance the cost of wage subsidies. We thus proceed to compare after-tax profits in the two regimes.

Let $\tau_{0}$ stand for the initial value of the profit tax rate when the when the minimum wage scheme is in place. Then, using equations (6), (10), (11) and (12) we find that the (labour) income tax rate is,

$$
t=1-\frac{a\left(2-\tau_{0}\right)}{2(1-\tau)\left[a(\phi-1)+b\left(2-\tau_{0}\right) \phi\right]}
$$

Using now the government budget constraint applying to the wage subsidies case (equation (15), we find that the profit tax rate which would result if the subsidy scheme was implemented would be 


$$
\tau_{C}=2-\frac{a\left[a(2 \phi-1)-2 b\left(2-\tau_{0}\right) \phi\right]}{b a(\phi-1)-b^{2}\left(2-\tau_{0}\right) \phi} .
$$

After some manipulations we find that after-tax profits are higher under the wage subsidies scheme if,

$$
\phi>\frac{\left[-2\left(2-\tau_{0}\right)+(b / a)\left(2-\tau_{0}\right)^{2}+(a / b)\left(1-\tau_{0}\right)\right]}{\left[1-(b / a)\left(2-\tau_{0}\right)\right]\left[-2\left(2-\tau_{0}\right)^{2}+(b / a)\left(2-\tau_{0}\right)^{2}+(a / b)\left(1-\tau_{0}\right)\right]} .
$$

Using equation (21) which pins down the combinations of $(a / b)$ and $\tau$ for different values of $\mu$ and $\phi$, the reader can easily verify that inequality (23) is satisfied for any empirically relevant parameter values. For example, in Figure 5 the two schedules depict the combinations of $(a / b)$ and $\tau$ for which after-tax profits remain unchanged for two values of $\phi$ (the solid schedule is for $\phi=0.2$, whereas the dashed schedule is for $\phi=0.3$ ), with higher values of $\phi$ shifting these schedules further inwards. Given that these values of $\phi$ are even lower than the lowest end of plausible values, and that points above these schedules indicate higher after-tax profits under the subsidy scheme, we infer (see also Figure 4) that if the median voter is willing to support the subsidy scheme, then after-tax profits will also be higher. We thus conclude that the efficiency-enhancing policy of wage subsidies will most likely lead to a sharing of the benefits of increased efficiency if those that mainly benefit from the subsidy (i.e., the owners of firms) are called upon to finance its cost. 


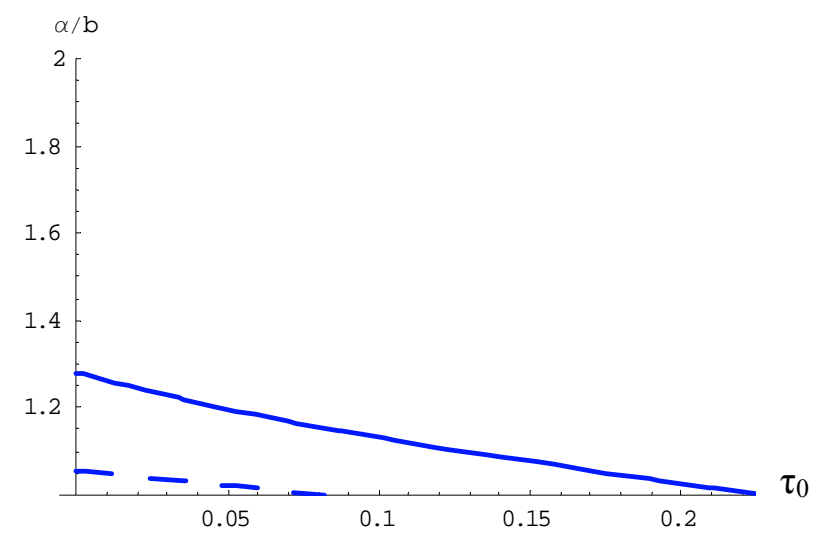

Figure 5: Combinations of $a / b$ and $\tau$ for equal after-tax profits (solid schedule for $\phi=0.2$, and dashed schedule for $\phi=0.3$ )

\section{Heterogeneous Labour}

An objection to the analysis presented in the previous section may relate to our assumption of a homogeneous labour force, which implies high government outlays as the wage subsidy is received by all workers. Another objection to our analysis may also be that there are differences in the probability of unemployment among workers due to the presence of a minimum wage, with the less able workers experiencing a higher incidence of unemployment. Since both of these objections to the analysis presented in the previous section are empirically relevant, we proceed with an examination of their importance for our results.

We assume that there are two groups of workers. A proportion $\theta$ of all workers have $\kappa$ units of effective labour at their disposal, whereas the rest of the workers have $\lambda$ units of (effective) labour at their disposal. We assume that $\kappa<1<\lambda$, and choose units in such way so that both the total number of workers and the aggregate effective labor supply is equal to one, i.e.,

$$
L_{S}=\kappa \theta+\lambda(1-\theta)=1 .
$$

This implies that the competitive (full employment) wage rate per unit of effective labour will be equal, as in Section 2, to $w_{c}=a-b$. We assume that each effective 
unit of labour earns the same wage rate, which implies that all workers are perfectly substitutable after adjusting for ability, and that the allocation of talent (or ability) across firms does not affect production costs. ${ }^{13}$

\subsection{Minimum Wages}

The demand for effective units of labour resulting from profit maximization will again be given by, $L_{d}=(a-w) / b$, with $w$ now standing for the wage rate per effective unit of labour. Let $y$ stand for the minimum wage (income per worker) that each firm has to pay in order to employ a worker. Then, as long as $\lambda w_{c}>y>\kappa w_{c}$, some of the less skilled (unskilled) workers will be unemployed, since in order to employ all of them the firms would have to pay to them more than the value of their marginal product. Firms will be willing to employ unskilled workers up to the point where the marginal product per effective unit of labour (which is the wage rate) times the effective units of labour per unskilled worker is equal to the legislated minimum that a worker must be paid per unit of time, i.e.,

$$
y=\kappa w .
$$

At the wage rate per effective unit of labour, w(as implied by the stipulated minimum compensation, $y$, that the firm has to pay in order to employ a worker), the difference between the number of effective units of labour supplied and demanded is

$$
L_{S}-L_{d}=\kappa \theta+\lambda(1-\theta)-\frac{a-w}{b}=1-\frac{a-w}{b}
$$

\footnotetext{
${ }^{13}$ Assuming that skilled and unskilled workers are not perfect substitutes, implies that if the median voter is a skilled worker who is always employed she would not be willing to vote for a minimum wage (for unskilled workers) higher than the competitive wage since it would be in her interest to ensure the maximum employment of unskilled workers.
} 
which further implies that the number of (unskilled) unemployed workers, and (since the total number of skilled plus unskilled workers has also been set equal to one) the aggregate unemployment rate will be equal to,

$$
u=\frac{L_{S}-L_{d}}{\kappa}=\frac{b-a+w}{\kappa b}
$$

Equations (25) and (26), in turn, determine $w$ and $u$ for any politically determined value of the minimum income (wage per unskilled worker), $y$. It is obvious that a larger value of $y$ implies that fewer unskilled individuals will be employed, that the marginal product of (effective) labour will be higher and that the wage rate per effective unit of labour will be higher. A rise in minimum wages thus results in an increase in the pre-tax incomes of those remaining in employment - directly for employed unskilled workers, and indirectly for skilled workers by increasing the wage rate per effective unit of labour.

The government budget constraint is similar to equation (6), i.e.

$$
t w(1-u)+\tau \pi=\phi w u(1-t)
$$

although in the present case the relevant wage is not the minimum stipulated by the government, but the wage rate per effective unit of labour.

We assume that the number of unskilled workers in the labour force is smaller than the number of skilled workers, i.e., $\theta<0.5$. This implies that the median voter is a skilled worker. (Had we assumed that the median voter is an unskilled worker, the analysis and the results would be similar to the ones obtained in the previous section since the median voter would again face a positive probability of unemployment.) The utility of the median voter is,

$$
U_{M V}=\lambda w(1-t)
$$

Using equations (25), (26) and (27), we can rewrite equation (28) as, 


$$
U_{M V}=\lambda \frac{(a-(y / \kappa))^{2}(\tau-2)(1+\phi \kappa)+\phi \kappa 2 b[a(1-\tau)-(y / \kappa)(2-\tau)]}{2[a-(y / \kappa)+\phi \kappa(b+a-(y / \kappa))]^{2}} .
$$

Maximizing equation (29) with respect to $y$ (the legislated minimum compensation per person) yields a quadratic equation in $y$, which has only one admissible solution (i.e., the other root for $y$ implies a wage rate per effective unit of labour such that the unemployment rate is $100 \%)$. This is,

$$
y^{*}=\kappa w^{*}=\frac{-\kappa\{(\tau-2)[a(1-\phi \kappa)-b \phi \kappa]+\sqrt{b(2-\tau) \phi \kappa[2 a(\phi \kappa-1)+b(2-\tau) \phi \kappa]}\}}{(2-\tau)(1-\phi \kappa)} .
$$

The resulting utility for the median voter is then found to be,

$U_{M V}=\frac{\lambda[(2-\tau)((a-b) \phi-a)+\mu]}{\left[(2-\tau)^{2}\left(1-\phi^{2}\right) b \phi-\mu\right] \phi}\left[b^{2}(2-\tau) \tau \phi-b(4-(2+a) \tau)(1-\phi)-\left(b \tau+\phi-\phi^{-1}\right) \mu\right]$

where,

$$
\mu=\sqrt{b(2-\tau) \phi[2 a(1-\phi)+b(2-\tau) \phi]} .
$$

\subsection{Wage Subsidies}

As in the previous section, we consider a wage subsidy scheme such that the total pre-tax income of each unskilled worker (full-employment wage income plus the subsidy) is equal to the value of $y^{*}$ as given by equation (30). We assume that at the competitive (i.e., full employment) wage rate, the pre-tax earnings of skilled workers $\left(=\lambda w_{c}=\lambda(a-b)\right)$ are higher than $y^{*}$. Then, the aggregate subsidy payments which must be incurred by the government are equal to the difference between the wage rate per effective unit of labour implied by the imposition of $y^{*}$ and the competitive wage rate times the total supply of effective labour units by unskilled workers, 


$$
s=\left(w^{*}-w_{c}\right) \kappa \theta=\frac{b(2-\tau)-\sqrt{b(2-\tau) \phi \kappa[2 a(\phi \kappa-1)+b(2-\tau) \phi \kappa]}}{(2-\tau)(1-\phi \kappa)} \kappa \theta
$$

Assuming that only the (wage) income tax rate adjusts so as to satisfy the government budget constraint, implies that the value of the income tax rate is,

$$
t_{c}=\frac{2 s-\tau b}{2\left[w^{*} \kappa \theta+(a-b) \lambda(1-\theta)\right]} .
$$

Using equations (28), (32) and (33) we find that the welfare of the median voter under the wage subsidy scheme is,

$$
U_{M V}=\frac{(a-b) \lambda(2-\tau)[2(a-b)+b \tau](1-\phi)}{2 a(2-\tau)(1-\phi)-2 b(2-\tau)[(1-\theta) \lambda(1-\phi)-\theta \kappa \phi]-2 \theta \kappa \mu} .
$$

We note that, in comparison with the minimum wage scheme, the change in the (skilled) median voter's welfare comes from two sources: first, from the reduction in the wage rate per effective unit of labour brought about by the increase in employment, and second from the change in the tax rate. The latter change is ambiguous. On the one hand there is an expansion of the tax base as aggregate output expands, but on the other hand the government must finance the more costly wage subsidies (relative to unemployment benefits). The overall impact on the median voter's welfare relative to the minimum wage scheme is again, as in the previous section, a-priori ambiguous.

In Figure 6, the dashed schedule depicts the locus of combinations of $a / b$ and $\tau$ for which the median voter is indifferent between the wage subsidy and minimum wage schemes, for $\theta=0.4, \kappa=0.8$, and $\phi=0.85$. Combinations of $a / b$ and $\tau$ which are below this schedule confer higher utility to the median voter when minimum wages are in place, whereas for points above the schedule, wage subsidies are preferable. For ease of comparison, the solid schedule (reproduced from Figures 2-4) represents the combinations $a / b$ and $\tau$ for which the median voter is indifferent 
between the wage subsidy and minimum wage schemes in the case of a homogeneous labour force. Although these schedules have been drawn for a set of particular parameter values, we wish to stress that for all sets of plausible parameter values we have experimented with the same pattern emerges, i.e., the schedule for the heterogeneous labour force lies everywhere above the schedule for the homogeneous labour force thus making it less likely that actual combinations will lie above this curve. We thus conclude that allowing for a heterogeneous labour force makes the political viability of wage subsidies even less likely than in the case of homogeneous labour. $^{14}$

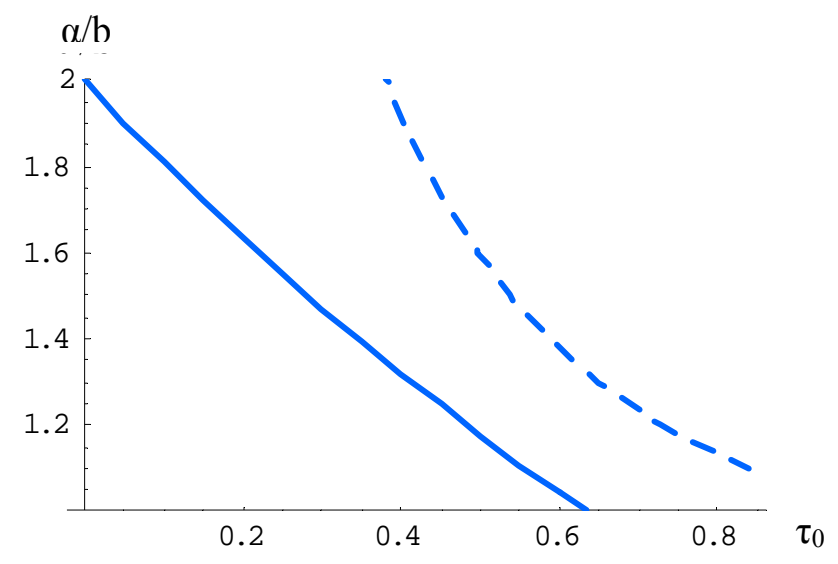

Figure 6: Homogeneous (solid schedule) and heterogeneous (dashed schedule) labour force combinations of $a / b$ and $\tau$ required for the adoption of subsidies

We now consider the case that it is only the profit tax rate which adjusts to finance the cost of wage subsidies. Unlike in the case of homogeneous labour, the skilled median voter will be against the granting of employment subsidies since she will face a reduction in the wage rate per effective unit of labour, without at the same time experiencing an improvement of her employment prospects (since only the unskilled

\footnotetext{
${ }^{14}$ Another finding of our analysis is that the higher is the difference in the endowment of effective labour supply between skilled and unskilled workers (a proxy for income inequality), the less likely it becomes that wages subsidies will be politically viable, i.e., a - ceteris paribus - fall in $\kappa$ results in an outward shift of the dashed schedule.
} 
face unemployment spells). The existence of a heterogeneous labour force thus reduces the political viability of wage subsidies even when the burden of financing them falls solely on profit recipients.

\section{Concluding Remarks}

The analysis of the previous sections explained both the skepticism of workers and the enthusiasm of firm owners for the adoption of a wage subsidy scheme instead of minimum wages (or, of other systems of income support which effectively operate like a minimum wage system). Although the politico-economic equilibrium in the

present paper has been identified with the wishes of a citizen whose sole source of income is from the sale of her labour services, the influence of special interest groups in democratic politics should not be ignored. Following Grossman and Helpman (2001), we can think of a policymaker whose policy preferences are shaped not only about "average" voter-cum-worker well-being but also from her desire to satisfy the demands of some powerful interest groups. Both trade unions and employers associations are good examples of such special interest groups. However, since we can identify the well being of the "average" worker as being the objective of trade unions as well, we can approximate the policymaker's preferences as a weighted average of the welfare of the "average" worker and of the "average" employer. The weights will reflect the policymaker's concern for the "average" voter's-cumworker's welfare relative to her taste for the benefits accruing to her from pursuing policies to the interest of the "average" employer (i.e., what Grossman and Helpman term "campaign contributions"). It can then be shown that as long as the policymaker places enough weight to the "campaign contributions" of the special interest group 
representing the employer's association, ${ }^{15}$ the granting of wage subsidies can become politically viable, and the politico-economic equilibrium move closer to the more efficient use of wage subsidies. ${ }^{16}$

The above arguments notwithstanding, it is clear that the political viability of a wage subsidy scheme depends on shaking off the impression that, despite being a more efficient solution than minimum wages to unemployment or poverty problems, it is an implicit subsidy to profit recipients since it induces a fall in the wage rate. This implies that proposals about the establishment of wage subsidy schemes may increase their political viability if they become part of a larger policy package guaranteeing that the rise in output engineered by the move to wage subsidies is shared among the social partners.

\footnotetext{
${ }^{15}$ However, no analytical solutions are available in this case, and there is no firm empirical evidence about the relative weight that policymakers place on "campaign contributions". The only available evidence comes from studies of trade policy. For example, in their studies of US trade policy Goldberg and Maggi (1999) and Gawande and Bandyopadhyay (2000)) estimate that the weight that policymakers place on general welfare is between one hundred and three thousand times larger than the weight attached to campaign contributions.

${ }^{16}$ An important property of lobbying models in which all relevant special interest groups compete for influencing the decisions of the policymaker is that the resulting equilibrium need not deviate from the one maximizing aggregate social welfare (see, Grossman and Helpman (2001), ch. 8).
} 


\section{$\underline{\text { References }}$}

Alesina, A., and Rodrik, D., (1994), "Distributive policies and economic growth", Quarterly Journal of Economics, 109, 465- 490.

Card, D., and Krueger, A., (1995), Myth and Measurement: The New Economics of the Minimum Wage, Princeton University Press, Princeton: New Jersey.

Cox, J.C, and Oaxaca, R.L., (1982), "The political economy of minimum wage legislation”, Economic Inquiry, 20, 533-555.

Dolado J. J., F. Felgueroso, and J. Jimeno, (2000), "The role of the minimum wage in the welfare state: An appraisal”, IZA Discussion Paper No. 152.

Downs, A., (1957), An economic theory of democracy, Harper and Row, New York:NY.

Dreze, J. (2002), "Economic and Social Security: The Role of the EU," De Economist, 150, 1-18.

Freeman R. B., (1996), "The minimum wage as a redistributive tool”, Economic Journal, 106, 639-649.

Gawande, K. and K. Bandyopadhyay, (2000), "Is protection for sale? A test of the Grossman-Helpman theory of endogenous protection", Review of Economics and Statistics, 89, 139-152.

Goldberg, P. and G. Maggi, (1999), "Protection for sale: An empirical investigation", American Economic Review, 89, 1135-1155.

Grossman, G. M., and E. Helpman, (2001), Special interest politics, The MIT Press, Cambridge: MA.

Knabe, A., (2006), "Marginal wage subsidies: a redistributive instrument for employment creation", Otto-von-Guericke-University Magdeburg, FEMM Working Paper No. 16/2006.

Knabe, A., R. Schoeb, and J. Weimann (2006), "Marginal employment subsidization: A new concept and a reappraisal", Kyklos, 59, (forthcoming).

Manning, A., (2003), Monopsony in Motion: Imperfect Competition in Labor Markets, Princeton University Press, Princeton:NJ.

Neumark, D. and W.. Wascher, (2000), "Minimum wages and employment: A case study of the fast-food industry in New Jersey and Pennslylvania:Comment", American Economic Review, 90,5, 1362-1396.

OECD, (1994), Jobs Study, OECD, Paris.

OECD, (1998), Employment Outlook, OECD, Paris.

OECD, (1999), Benefit Systems and Work Incentives, Paris. 
Orszag, J. M., and D. Snower (2000): "The Effectiveness of Employment Vouchers: A Simple Approach", German Economic Review 1, 385-419.

Orszag, J. M., and D. Snower (2003): “Designing Employment Subsidies”, Labour Economics 10, 557-572.

Phelps, E., (1994), "Low-wage employment subsidies versus the welfare state", American Economic Review, 84, 2, 54-58.

Phelps, E., (1997), Rewarding Work. How to Restore Participation and Self-Support to Free Enterprise, Harvard University Press, Cambridge:Mass.

Poterba, J.M., (1997), "Rate of return to corporate capital and factor shares: New estimates using revised national income accounts and capital stock data", NBER Working Paper No.6263.

Saint- Paul, G., (2000), The political economy of labor market institutions, Oxford University Press, Oxford.

Schoeb, R., and J.Weimann(2003), "Kombilohn: Die Magdeburger Alternative", Perspektiven der Wirtschaftspolitik, 4, 1-16.

Sinn, H.-W., (2000), "The threat to the German welfare state", Atlantic Economic Journal, 3, 279-294.

Sinn, H. -W., (2005a), "Migration and Social Replacement Incomes: How to Protect Low-Income Workers in the Industrialized Countries Against the Forces of Globalization and Market Integration", International Tax and Public Finance, 12, 375-393

Sinn, H.-W., (2005b), "Why minimum wages hurt Germany”, Ifo Viewpoint No. 64.

Sinn, H.-W., (2006), "The next welfare state”, Ifo Viewpoint No. 72.

Sobel, R.S., (1999), "Theory and evidence on the political economy of the minimum wage”, Journal of Political Economy, 107, 761-785. 


\title{
CESifo Working Paper Series
}

\author{
(for full list see www.cesifo-group.de)
}

1748 Olaf Posch and Klaus Waelde, Natural Volatility, Welfare and Taxation, June 2006

1749 Christian Holzner, Volker Meier and Martin Werding, Workfare, Monitoring, and Efficiency Wages, June 2006

1750 Steven Brakman, Harry Garretsen and Charles van Marrewijk, Agglomeration and Aid, June 2006

1751 Robert Fenge and Jakob von Weizsäcker, Mixing Bismarck and Child Pension Systems: An Optimum Taxation Approach, June 2006

1752 Helge Berger and Michael Neugart, Labor Courts, Nomination Bias, and Unemployment in Germany, June 2006

1753 Chris van Klaveren, Bernard van Praag and Henriette Maassen van den Brink, A Collective Household Model of Time Allocation - a Comparison of Native Dutch and Immigrant Households in the Netherlands, June 2006

1754 Marko Koethenbuerger, Ex-Post Redistribution in a Federation: Implications for Corrective Policy, July 2006

1755 Axel Dreher, Jan-Egbert Sturm and Heinrich Ursprung, The Impact of Globalization on the Composition of Government Expenditures: Evidence from Panel Data, July 2006

1756 Richard Schmidtke, Private Provision of a Complementary Public Good, July 2006

1757 J. Atsu Amegashie, Intentions and Social Interactions, July 2006

1758 Alessandro Balestrino, Tax Avoidance, Endogenous Social Norms, and the Comparison Income Effect, July 2006

1759 Øystein Thøgersen, Intergenerational Risk Sharing by Means of Pay-as-you-go Programs - an Investigation of Alternative Mechanisms, July 2006

1760 Pascalis Raimondos-Møller and Alan D. Woodland, Steepest Ascent Tariff Reforms, July 2006

1761 Ronald MacDonald and Cezary Wojcik, Catching-up, Inflation Differentials and Credit Booms in a Heterogeneous Monetary Union: Some Implications for EMU and new EU Member States, July 2006

1762 Robert Dur, Status-Seeking in Criminal Subcultures and the Double Dividend of ZeroTolerance, July 2006 
1763 Christa Hainz, Business Groups in Emerging Markets - Financial Control and Sequential Investment, July 2006

1764 Didier Laussel and Raymond Riezman, Fixed Transport Costs and International Trade, July 2006

1765 Rafael Lalive, How do Extended Benefits Affect Unemployment Duration? A Regression Discontinuity Approach, July 2006

1766 Eric Hillebrand, Gunther Schnabl and Yasemin Ulu, Japanese Foreign Exchange Intervention and the Yen/Dollar Exchange Rate: A Simultaneous Equations Approach Using Realized Volatility, July 2006

1767 Carsten Hefeker, EMU Enlargement, Policy Uncertainty and Economic Reforms, July 2006

1768 Giovanni Facchini and Anna Maria Mayda, Individual Attitudes towards Immigrants: Welfare-State Determinants across Countries, July 2006

1769 Maarten Bosker and Harry Garretsen, Geography Rules Too! Economic Development and the Geography of Institutions, July 2006

1770 M. Hashem Pesaran and Allan Timmermann, Testing Dependence among Serially Correlated Multi-category Variables, July 2006

1771 Juergen von Hagen and Haiping Zhang, Financial Liberalization in a Small Open Economy, August 2006

1772 Alessandro Cigno, Is there a Social Security Tax Wedge?, August 2006

1773 Peter Egger, Simon Loretz, Michael Pfaffermayr and Hannes Winner, Corporate Taxation and Multinational Activity, August 2006

1774 Jeremy S.S. Edwards, Wolfgang Eggert and Alfons J. Weichenrieder, The Measurement of Firm Ownership and its Effect on Managerial Pay, August 2006

1775 Scott Alan Carson and Thomas N. Maloney, Living Standards in Black and White: Evidence from the Heights of Ohio Prison Inmates, 1829 - 1913, August 2006

1776 Richard Schmidtke, Two-Sided Markets with Pecuniary and Participation Externalities, August 2006

1777 Ben J. Heijdra and Jenny E. Ligthart, The Transitional Dynamics of Fiscal Policy in Small Open Economies, August 2006

1778 Jay Pil Choi, How Reasonable is the 'Reasonable’ Royalty Rate? Damage Rules and Probabilistic Intellectual Property Rights, August 2006

1779 Ludger Woessmann, Efficiency and Equity of European Education and Training Policies, August 2006 
1780 Gregory Ponthiere, Growth, Longevity and Public Policy, August 2006

1781 Laszlo Goerke, Corporate and Personal Income Tax Declarations, August 2006

1782 Florian Englmaier, Pablo Guillén, Loreto Llorente, Sander Onderstal and Rupert Sausgruber, The Chopstick Auction: A Study of the Exposure Problem in Multi-Unit Auctions, August 2006

1783 Adam S. Posen and Daniel Popov Gould, Has EMU had any Impact on the Degree of Wage Restraint?, August 2006

1784 Paolo M. Panteghini, A Simple Explanation for the Unfavorable Tax Treatment of Investment Costs, August 2006

1785 Alan J. Auerbach, Why have Corporate Tax Revenues Declined? Another Look, August 2006

1786 Hideshi Itoh and Hodaka Morita, Formal Contracts, Relational Contracts, and the Holdup Problem, August 2006

1787 Rafael Lalive and Alejandra Cattaneo, Social Interactions and Schooling Decisions, August 2006

1788 George Kapetanios, M. Hashem Pesaran and Takashi Yamagata, Panels with Nonstationary Multifactor Error Structures, August 2006

1789 Torben M. Andersen, Increasing Longevity and Social Security Reforms, August 2006

1790 John Whalley, Recent Regional Agreements: Why so many, why so much Variance in Form, why Coming so fast, and where are they Headed?, August 2006

1791 Sebastian G. Kessing and Kai A. Konrad, Time Consistency and Bureaucratic Budget Competition, August 2006

1792 Bertil Holmlund, Qian Liu and Oskar Nordström Skans, Mind the Gap? Estimating the Effects of Postponing Higher Education, August 2006

1793 Peter Birch Sørensen, Can Capital Income Taxes Survive? And Should They?, August 2006

1794 Michael Kosfeld, Akira Okada and Arno Riedl, Institution Formation in Public Goods Games, September 2006

1795 Marcel Gérard, Reforming the Taxation of Multijurisdictional Enterprises in Europe, a Tentative Appraisal, September 2006

1796 Louis Eeckhoudt, Béatrice Rey and Harris Schlesinger, A Good Sign for Multivariate Risk Taking, September 2006 
1797 Dominique M. Gross and Nicolas Schmitt, Why do Low- and High-Skill Workers Migrate? Flow Evidence from France, September 2006

1798 Dan Bernhardt, Stefan Krasa and Mattias Polborn, Political Polarization and the Electoral Effects of Media Bias, September 2006

1799 Pierre Pestieau and Motohiro Sato, Estate Taxation with Both Accidental and Planned Bequests, September 2006

1800 Øystein Foros and Hans Jarle Kind, Do Slotting Allowances Harm Retail Competition?, September 2006

1801 Tobias Lindhe and Jan Södersten, The Equity Trap, the Cost of Capital and the Firm's Growth Path, September 2006

1802 Wolfgang Buchholz, Richard Cornes and Wolfgang Peters, Existence, Uniqueness and Some Comparative Statics for Ratio- and Lindahl Equilibria: New Wine in Old Bottles, September 2006

1803 Jan Schnellenbach, Lars P. Feld and Christoph Schaltegger, The Impact of Referendums on the Centralisation of Public Goods Provision: A Political Economy Approach, September 2006

1804 David-Jan Jansen and Jakob de Haan, Does ECB Communication Help in Predicting its Interest Rate Decisions?, September 2006

1805 Jerome L. Stein, United States Current Account Deficits: A Stochastic Optimal Control Analysis, September 2006

1806 Friedrich Schneider, Shadow Economies and Corruption all over the World: What do we really Know?, September 2006

1807 Joerg Lingens and Klaus Waelde, Pareto-Improving Unemployment Policies, September 2006

1808 Axel Dreher, Jan-Egbert Sturm and James Raymond Vreeland, Does Membership on the UN Security Council Influence IMF Decisions? Evidence from Panel Data, September 2006

1809 Prabir De, Regional Trade in Northeast Asia: Why do Trade Costs Matter?, September 2006

1810 Antonis Adam and Thomas Moutos, A Politico-Economic Analysis of Minimum Wages and Wage Subsidies, September 2006 